\title{
Healthcare Provider's General Perception and Attitude toward Pharmacists in Saudi Arabia
}

\author{
Yousef Ahmed Alomi ${ }^{1, *}$, Sarah Abdullah Al-Hathlool2, Marzooq Abdullah Marzooq Albadi ${ }^{3}$, \\ Maryam Ibrahim Almulhim², Yousef Aboshalaf ${ }^{4}$, Mytham Al-Ethan ${ }^{5}$ \\ ${ }^{1}$ The Former General Manager of General Administration of Pharmaceutical Care and Former Head, National Clinical Pharmacy \\ and Pharmacy Practice and Pharmacy $R$ and D Administration, Ministry of Health, Riyadh, SAUDI ARABIA. \\ ${ }^{2}$ Clinical Pharmacy Staff, Ministry of Health, Riyadh, SAUDI ARABIA. \\ ${ }^{3}$ Internal Medicine Consultant, Security Forces Hospital, Riyadh, SAUDI ARABIA. \\ ${ }^{4}$ Former Head of Pharmacy Services, King Fahad Hospital, Alhasa, Ministry of Health, Riyadh, SAUDI ARABIA. \\ ${ }^{5}$ Assistant Head of Pharmacy Services, King Fahad Hospital, Ministry of Health, Riyadh, SAUDI ARABIA.
}

Received: 12 September 2018;

Accepted: 23 November 2018

*Correspondence to:

Dr. Yousef Ahmed Alomi,

The Past General Manager of General Administration of Pharmaceutical Care Head, National Clinical Pharmacy and Pharmacy practice Head, Pharmacy $R$ and $D$ Administration, Ministry of Health, P.O.BOX 100, Riyadh 11392, Riyadh, SAUDI ARABIA. Email:yalomi@gmail.com

Copyright: () the author(s),publisher and licensee Indian Academy of Pharmacists. This is an open-access article distributed under the terms of the Creative Commons Attribution Non-Commercial License, which permits unrestricted non-commercial use, distribution, and reproduction in any medium, provided the original work is properly cited.

\begin{abstract}
Objective: To explore the Healthcare professionals' perception and attitude towards pharmacists in Saudi Arabia. Methods: It is a 4-month cross-sectional survey of healthcare professionals' perception towards pharmacists. The survey consisted of two-part of demographic information and second part forty-nine questions divided into four domains. It included domain one: healthcare providers general perception of pharmacist domain 2: Healthcare professionals' perception of pharmaceutical care services, domain 3: healthcare professionals' perception of visiting ambulatory care and domain 4: Healthcare professionals' perception of pharmacists' relationship and counseling. All types of healthcare professionals included in the study. The 5-point Likert response scale system was used. The questions were open and close-ended. The survey was distributed through social media by using WhatsApp to more than one thousand healthcare professionals overall the Kingdom of Saudi Arabia. The survey was made as an electronic format and it analyzed and discussed domain one: healthcare providers' general perception of pharmacist through monkey survey system. Results: The total responders were (170) healthcare providers. Of those 150 (93.8\%) were Saudi and 10 (6.25\%) were non-Saudi. The gender distribution was $129(75.9 \%)$ females and $41(24.1 \%)$ were males. The majority of patient visited the pharmacy in the past 12-months more than ten times were $53(31.36 \%)$ while $40(23.67 \%)$ attended as visitors for 5-9 times. Most of the patient (143 (87.2\%)) spent less than 16 minutes waiting for the medication at the pharmacy. The statement said by pharmacists with highest score was "the pharmacist had the significant role in preventing medications errors (4.76), pharmacy job is vital in our society (4.74), the pharmacist participates in patient therapeutic plan as part of the medical team (4.5)". Also, the pharmacist is the first person to be asked about medications (4.47), Healthcare professionals know the clinical pharmacist and his role in patients' care (4.47). More than $60 \%$ of healthcare professionals will choose the pharmacy as specialty or suggest to the family members or friend to select the pharmacy as their profession. Most of the healthcare providers visited the pharmacy as the pharmacist knows more about drug doses and adverse drug reaction $98(58.33 \%)$ and the to seek pharmacists help in general health illness (96 (57.14\%)). Other reason for visiting the pharmacy to get free consultation $(49(29.17 \%))$ and since there is no need to have an appointment for pharmacy visit $(48(28.57 \%))$. Also, most of the healthcare professionals refused to utilize the pharmacy just for cosmetics (118 (70.23\%)). Conclusion: Most of the healthcare professionals had a real perception towards the pharmacist and his role in preventing medication errors and sharing in the therapeutic plan. The pharmacist should expand clinical pharmacy services at all healthcare institutions in Saudi Arabia since there is an acceptance for such concept.
\end{abstract}

Key words: Healthcare Provider, Perception, Attitude, Pharmacists, Ministry of Health, Saudi Arabia.

\section{INTRODUCTION}

The concept of pharmaceutical care founded by Hepler and Strand in the early 1990s. ${ }^{[1]}$ The American society of health system pharmacist (ASHP) released the guideline of pharmaceutical care and implementation method at all healthcare organizations. ${ }^{[2-3]}$ The pharmaceutical care focused changed from the physician to the patient. That is all care with the objective of the patient. In the past, the pharmacy services provided the services with a focus on the physician. That due to the not acceptable role of the clinical pharmacist within medical team and most of the physician in the past not recognized the pharmacist or had not acceptable perception. Several studies were published about healthcare professional's perception toward the pharmacist. ${ }^{[4-8]}$ The studies showed that difference and variations in attitudes and perception from one place to another one. It is difficult to find the local study about healthcare provider's perception with the pharmacist. In addition 
to Gulf or Middle East counties. The objective of the study to explore the healthcare professional's perception toward the pharmacist in Kingdom of Saudi Arabia (KSA).

\section{METHODS}

It is a 4-months cross-sectional survey of healthcare professional's perception of a pharmacist. The survey was consisted of two-part demographic information and second part forty-nine questions divided into four domains. It included domain one: healthcare providers General perception of pharmacist domain 2: Healthcare professionals' perception of pharmaceutical care services, domain 3: healthcare professionals' perception of visiting ambulatory care and domain 4: Healthcare professionals' perception of pharmacist's relationship and counseling. All type of healthcare professionals included in the study. The 5-point Likert response scale system was used. The questions were open and closed-ended. The survey was distributed through social media by using what's App to more than one thousand healthcare professionals overall Kingdom of Saudi Arabia. A messages reminder was sent to healthcare professional after two weeks and additional message reminders sent to healthcare professional after four weeks the survey was made in an electronic format and it analyzed domain one Primary or necessary information about healthcare professional's medication through survey monkey system.

\section{RESULTS}

The total responders were (170) healthcare providers. Of those $150(93.8 \%)$ was Saudi and $10(6.25 \%)$ was non-Saudi. The gender distribution 129 $(75.9 \%)$ was female and $41(24.1 \%)$ was male. Most of them were in age (18-44) 95.8\% and located at Riyadh region 69 (41.6\%), East Province region $36(21.7 \%)$ and Alhasa region $26(15.66 \%)$. The most educational level of the responders was bachelor's degree $126(76.4 \%)$ followed by Diploma $16(9.7 \%)$. Most of the healthcare providers were pharmacist $81(47.65 \%)$, others 33 (19.41\%), nurses $27(15.88 \%)$ and physician $23(13.53 \%)$. The majority of patient visited the pharmacy in the past 12 -months was 53 $(31.36 \%)$ more than ten times while $40(23.67 \%)$ attended (5-9 times). The majority of healthcare professional visited the pharmacy at evening time 79 (47.31\%) and morning 54 (32.34\%). Most of patient 143 (87.2\%) spent less than 16 minutes waiting for the medication from the pharmacy as explored in Table 1. The highest score statements related to pharmacist perceptions was the pharmacist had the significant role in preventing medications errors (4.76), pharmacy job is vital in our society (4.74), the pharmacist participates in patient therapeutic plan part of the medical team (4.5). Also, the pharmacist is the first person to ask him about the medications (4.47), Healthcare professionals knew about the clinical pharmacist and his role for the patients (4.47). Followed by calling the pharmacist by the doctor (3.89), the necessity of present school pharmacy (3.72) and the pharmacist has the very high social level (3.59). More than $60 \%$ of healthcare professionals will choose the pharmacy as professional specialty or suggest the family members or friend to select the pharmacy professional as explored in Table 2. The pharmacist shared in public education through the newspapers (3.84) and television and media (3.65) followed by public education exhibitors (3.67) and general school (3.55) as explored in Table 3. Most of the healthcare providers visited because the pharmacist knows more about drug doses and adverse drug reaction $98(58.33 \%)$ and the pharmacist to seek help in health diseases 96 (57.14\%). Followed by free consultation and $49(29.17 \%)$ and no need for an appointment for pharmacy visit 48 (28.57\%). Also, most of the healthcare professionals were refused to utilize the pharmacy just for cosmetics $118(70.23 \%)$ as explored in Table 4.

\section{DISCUSSION}

The concept of pharmaceutical care stated implementation at Ministry of health institution during the first pharmacy strategic plan in mid of 2000s.
Table 1: Demographic responder qualifications information.

\begin{tabular}{|c|c|c|}
\hline Items & $\begin{array}{l}\text { Response } \\
\text { Count }\end{array}$ & $\begin{array}{l}\text { Response } \\
\text { Percent }\end{array}$ \\
\hline \multicolumn{3}{|l|}{ Sex } \\
\hline Female & 129 & $75.9 \%$ \\
\hline Male & 41 & $24.1 \%$ \\
\hline Answered question & 170 & \\
\hline Skipped question & 0 & \\
\hline \multicolumn{3}{|l|}{ Nationality } \\
\hline Saudi & 150 & $93.75 \%$ \\
\hline Non-Saudi & 10 & $6.25 \%$ \\
\hline Answered question & 160 & \\
\hline Skipped question & 10 & \\
\hline \multicolumn{3}{|l|}{ Age } \\
\hline$<18$ & 0 & $0.00 \%$ \\
\hline $18-29$ & 127 & $75.60 \%$ \\
\hline $30-44$ & 34 & $20.24 \%$ \\
\hline $45-59$ & 7 & $4.17 \%$ \\
\hline $60+$ & 0 & $0.00 \%$ \\
\hline Answered question & 168 & \\
\hline Skipped question & 2 & \\
\hline \multicolumn{3}{|l|}{ Type of visit } \\
\hline Physician & 23 & $13.53 \%$ \\
\hline Dentist & 4 & $2.35 \%$ \\
\hline Pharmacist & 81 & $47.65 \%$ \\
\hline Nurse & 27 & $15.88 \%$ \\
\hline Others & 33 & $19.41 \%$ \\
\hline Answered question & 170 & \\
\hline Skipped question & 0 & \\
\hline \multicolumn{3}{|c|}{$\begin{array}{l}\text { In the last } 12 \text { months, the number of times visited } \\
\text { the pharmacy }\end{array}$} \\
\hline None & 6 & $3.55 \%$ \\
\hline 1 time & 15 & $8.88 \%$ \\
\hline 2 & 21 & $12.43 \%$ \\
\hline 3 & 19 & $11.24 \%$ \\
\hline 4 & 15 & $8.88 \%$ \\
\hline 5 to 9 & 40 & $23.67 \%$ \\
\hline 10 or more times & 53 & $31.36 \%$ \\
\hline Answered question & 169 & \\
\hline Skipped question & 1 & \\
\hline \multicolumn{3}{|c|}{ Time of Visiting the Pharmacy } \\
\hline Morning & 54 & $32.34 \%$ \\
\hline Evening & 79 & $47.31 \%$ \\
\hline Night & 34 & $20.36 \%$ \\
\hline Answered question & 167 & \\
\hline Skipped question & 3 & \\
\hline \multicolumn{3}{|c|}{ The waiting time to get the medications } \\
\hline$<5$ & 70 & $42.68 \%$ \\
\hline $5-10$ & 53 & $32.32 \%$ \\
\hline $11-15$ & 20 & $12.20 \%$ \\
\hline $16-20$ & 7 & $4.27 \%$ \\
\hline $21-25$ & 3 & $1.83 \%$ \\
\hline
\end{tabular}




\begin{tabular}{|c|c|c|}
\hline Items & $\begin{array}{l}\text { Response } \\
\text { Count }\end{array}$ & $\begin{array}{l}\text { Response } \\
\text { Percent }\end{array}$ \\
\hline $26-30$ & 3 & $1.83 \%$ \\
\hline $31-35$ & 0 & $0.00 \%$ \\
\hline $36-40$ & 1 & $0.61 \%$ \\
\hline $41-45$ & 1 & $0.61 \%$ \\
\hline $46-50$ & 0 & $0.00 \%$ \\
\hline $51-55$ & 1 & $0.61 \%$ \\
\hline $56-60$ & 1 & $0.61 \%$ \\
\hline نم رثك ا More than 60 & 4 & $2.44 \%$ \\
\hline Answered question & 164 & \\
\hline Skipped question & 6 & \\
\hline \multicolumn{3}{|c|}{$\begin{array}{l}\text { Total years of Experiences in Pharmacokinetic } \\
\text { services }\end{array}$} \\
\hline Doctorate degree & 6 & $3.64 \%$ \\
\hline Master degree & 8 & $4.85 \%$ \\
\hline Bachelor Degree & 126 & $76.36 \%$ \\
\hline Diploma & 16 & $9.70 \%$ \\
\hline High school & 8 & $4.85 \%$ \\
\hline Intermediate School & 0 & $0.00 \%$ \\
\hline Primary School & 1 & $0.61 \%$ \\
\hline Not educated & 0 & $0.00 \%$ \\
\hline Answered question & 165 & \\
\hline Skipped question & 5 & \\
\hline
\end{tabular}

The concept emphasized with the updated pharmaceutical care strategic planning in early $2012 .{ }^{[9]}$ The care changed from physician to the patients. The general administration of pharmaceutical released several pharmacy practice and clinical pharmacy program to the patient included but not limited to the medications safety, pain management services and the anticoagulation program. ${ }^{[10-12]}$ The healthcare professional's perception toward pharmacist is not well known in Saudi Arabia. The authors explored the healthcare professional's perception with the pharmacist in Kingdom of Saudi Arabia. The finding of the study showed half the healthcare professionals' responders were pharmacist and others maybe non-pharmacist that has implicated some bias of answering the question. It better to repeat the study and involved healthcare providers with equal responders. However, still you can at least come some results and conclusions from non-pharmacist professional's perception. The healthcare professionals visited several times in the last twelve months with majority of them came with follow up cases not first visit. Most of the healthcare professionals visited the pharmacy during event of period due they were busy during morning duty with their work and most of them visited community pharmacies non-hospitals pharmacies because the hospital pharmacy working at morning duty and cover with one to two pharmacists at evening and nigh duties. The results of number of visiting pharmacy by healthcare providers resemble what reported by Jose $\mathrm{J}$ et al. Khan MU et al. and Merks et al. as regular patients. ${ }^{[13-15]}$ The healthcare professionals spent more time during visiting the pharmacy with higher than the patient spent visits, which is maybe the healthcare professionals asking a lot and more discussion with the pharmacist. The healthcare professionals had excellent perception of pharmacist with role of pharmacist preventing medications errors. That has related the interaction between the pharmacist and healthcare professionals during dispensing medications to them. The healthcare professional's very good precept the pharmacist's involvement the pharmacist as part of medical team and participated in the therapeutic

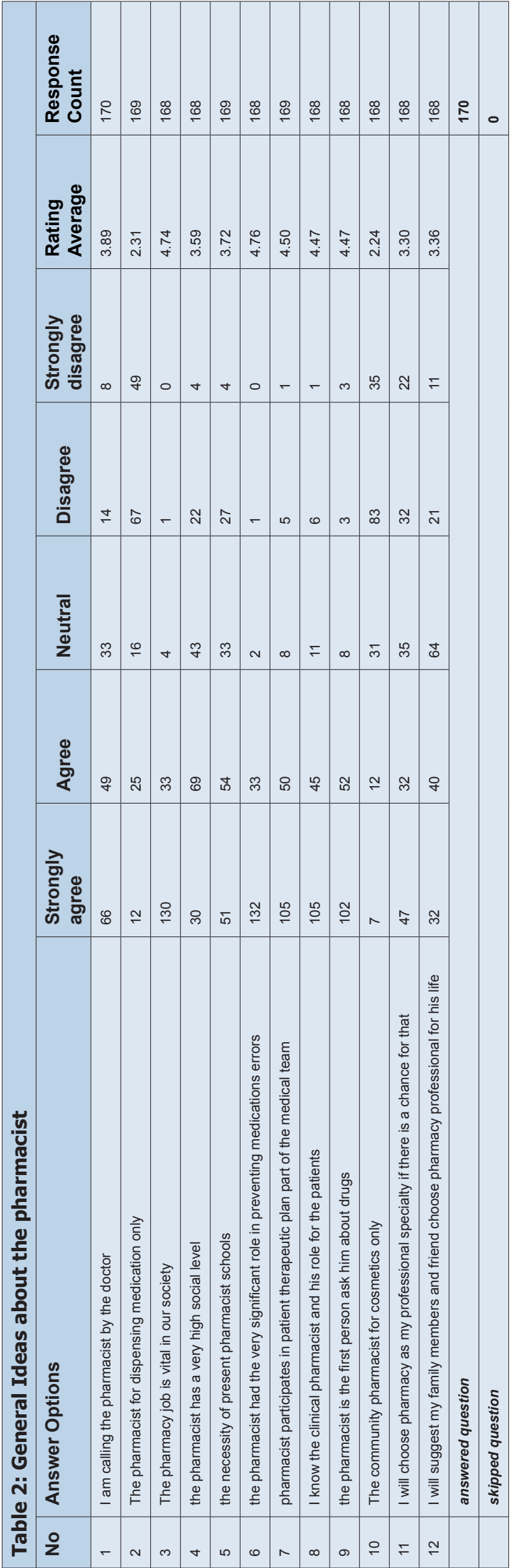




\section{Table 3: Pharmacist shares in public education through media.}

\begin{tabular}{|c|c|c|c|c|c|c|c|c|}
\hline No & Answer Options & $\begin{array}{l}\text { Strongly } \\
\text { agree }\end{array}$ & Agree & Neutral & Disagree & $\begin{array}{l}\text { Strongly } \\
\text { disagree }\end{array}$ & $\begin{array}{l}\text { Rating } \\
\text { Average }\end{array}$ & $\begin{array}{l}\text { Response } \\
\text { Count }\end{array}$ \\
\hline 1 & The pharmacist participates in public education in the schools & 43 & 57 & 29 & 27 & 12 & 3.55 & 168 \\
\hline 2 & $\begin{array}{l}\text { The pharmacist participates in medication public education through the } \\
\text { televisions and media }\end{array}$ & 48 & 60 & 33 & 21 & 6 & 3.73 & 168 \\
\hline 3 & $\begin{array}{l}\text { The pharmacist participates in medication public education through the } \\
\text { newspapers and magazines }\end{array}$ & 43 & 76 & 32 & 13 & 4 & 3.84 & 168 \\
\hline \multirow[t]{3}{*}{4} & The pharmacist participates in medication public education exhibitions & 44 & 54 & 43 & 22 & 4 & 3.67 & 167 \\
\hline & \multicolumn{7}{|l|}{ answered question } & 168 \\
\hline & \multicolumn{7}{|l|}{ skipped question } & 2 \\
\hline
\end{tabular}

Table 4: The reasons for patients ask the pharmacist
before the physician.
\begin{tabular}{l|l|l|l|} 
No. & Answer Options & $\begin{array}{l}\text { Response } \\
\text { Count }\end{array}$ & $\begin{array}{l}\text { Response } \\
\text { Percent }\end{array}$ \\
\hline 1 & To seek help in health diseases & 96 & $57.14 \%$ \\
\hline 2 & No need for appointment for pharmacy visits & 48 & $28.57 \%$ \\
\hline 3 & Fee consultation & 49 & $29.17 \%$ \\
\hline 4 & $\begin{array}{l}\text { The pharmacist knows more about drug } \\
\text { doses and adverse drug reaction }\end{array}$ & 98 & $58.33 \%$ \\
\hline 5 & I prefer the pharmacist consultations & 28 & $16.67 \%$ \\
\hline 6 & Other (please specify) & 7 & $4.17 \%$ \\
\hline & answered question & 168 & \\
\hline & skipped question & 2 & \\
\hline
\end{tabular}

plan. It resemble what reported by Jose $\mathrm{J}$ et al. and Khan MU et al. as patient perceptions not as healthcare professional. ${ }^{[13-14]}$ The healthcare professional's first-person asking about medications was pharmacist and had knowledge about the role of clinical pharmacist. That has related to new generation of pharmacist had Pharm D and residency graduates with significant pharmacist role in patient care. The finding of medication information of pharmacist better than physician resemble what reported by Khan MU et al. ${ }^{[14]}$ and better than what reported by Oshima $\mathrm{S}$ et al..$^{[8]}$ as patient perceptions. That's related more development of the pharmacy professional than that's country. The healthcare professionals considered the pharmacy job is vital at our society and most of them recommended to their family or fried to be the pharmacist. The healthcare professionals considered the pharmacist as public educator through participating with newspaper, television and social media. The majority of healthcare professionals visited the pharmacy because the pharmacist knows more about medications and drug doses. That is good perception gave the pharmacist to expand the pharmacy services and their role to the public. In addition, the healthcare professionals visited the pharmacy demand of information about health and refuse to consider the pharmacist as resources only for cosmetic.

\section{CONCLUSION}

The healthcare professionals had an excellent perception of a pharmacist and their performance. Targeting to expand the role of pharmacist and pharmacy services at healthcare organization in Kingdom of Saudi Arabia.

\section{ACKNOWLEDGEMENT}

None.

\section{CONFLICT OF INTEREST}

The authors declare no conflict of interest.

\section{ABBREVIATIONS}

ASHP: American society of health system pharmacist; MOH: Ministry of Health; KSA: Kingdom of Saudi Arabia.

\section{REFERENCES}

1. Hepler CD, Strand LM. Opportunities and responsibilities in pharmaceutical care. Am J Hosp Pharm. 1990;47(3):533-43.

2. ASHP. ASHP Statement on Pharmaceutical Care. Am J Hosp Pharm. 1993;50:1720-3.

3. American Society of Health-System Pharmacists. ASHP guidelines on a standardized method for pharmaceutical care. American Society of Health-System Pharmacists. Am J Heal Pharm. 1996;53(14):1713-6.

4. Schindel TJ, Yuksel N, Breault R, Daniels J, Varnhagen S, Hughes CA. Perceptions of pharmacists' roles in the era of expanding scopes of practice. Res Soc Adm Pharm. 2017;13(1):148-61.

5. Basak SC, Van MJWF, Sathyanarayana D. The changing roles of pharmacists in community pharmacies: Perception of reality in India. Pharm World Sci. 2009;31(6):612-8.

6. Eades CE, Ferguson JS, O'Carroll RE. Public health in community pharmacy: A systematic review of pharmacist and consumer views. BMC Public Health. 2011;11(1):582.

7. Renberg T, Lindblad ÅK, Tully MP. Exploring subjective outcomes perceived by patients receiving a pharmaceutical care service. Res Soc Adm Pharm. 2006;2(2):212-31.

8. Oshima S, Senoo K, Negishi A, Akimoto H, Kutsuma N, Juni K, et al. Identification of the Discrepancies between Pharmacist and Patient Perception of the Pharmacist's Role as an Advisor on Drug Therapy Based on Social Science Theory. Biol Pharm Bull. 2016;39(39):313-22.

9. Alomi YA, Alghamdi SJ, Alattyh RA. Strategic Plan of General Administration of Pharmaceutical Care at Ministry of Health in Saudi Arabia 2012- 2022. J Pharm Pharm Scien. 2015;1(13):1-8.

10. Alomi YA. National Pharmacy Practice Programs at Ministry of Health in Saudi Arabia. J Pharm Pharm Scien. 2015;1(2):17-8.

11. Alomi YA. National Medication Safety Program at Ministry of Health in Saudi Arabia. J Pharmacovigil. 2015;3:e145.

12. Alomi YA. National Pharmacy Pain Management Program at Ministry of Health in Saudi Arabia. J Pharmacol Clin Res. 2017;3(2).

13. Jose J, Al Shukili MN, Jimmy B. Public's perception and satisfaction on the roles and services provided by pharmacists - Cross sectional survey in Sultanate of Oman. Saudi Pharm J. 2015;23(6):635-41.

14. Khan MU, Khan AN, Ahmed FR, Feroz Z, Rizvi SA, Shah S, et al. Patients' opinion of pharmacists and their roles in health care system in Pakistan. $\mathrm{J}$ Young Pharm. 2013;5(3):90-4

15. Merks P, Świeczkowski D, Jaguszewski MJ. Patients' perception of pharmaceutical services available in a community pharmacy among patients living in a rural area of the United Kingdom. Pharm Pract (Granada). 2016;14(3).

Cite this article as: Alomi YA, Al-Hathlool SA, Albadi MAM, Almulhim MI, Aboshalaf Y, Al-Etha M. Healthcare Provider's General Perception and Attitude toward Pharmacists in Saudi Arabia. J Pharm Pract Community Med. 2018;4(4):222-5. 